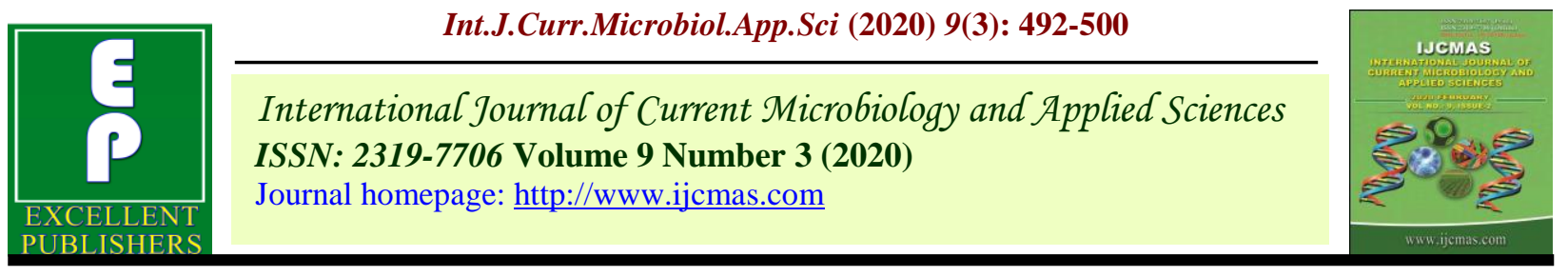

Original Research Article

https://doi.org/10.20546/ijcmas.2020.902.057

\title{
Agriculture for Poverty Alleviation: The Changing Role of Agricultural Extension in Developing Nations
}

\author{
Chandan Kumar Panda, Aditya Karn* and Ravindra Kumar Sohane \\ Department of Extension Education, Bihar Agricultural University, Sabour, \\ Bhagalpur-813 210, India \\ *Corresponding author
}

\begin{tabular}{l} 
Key w o r d s \\
$\begin{array}{l}\text { Agriculture, } \\
\text { Poverty Alleviation, } \\
\text { rural economy }\end{array}$ \\
\hline Article Info \\
$\begin{array}{l}\text { Accepted: } \\
\text { 05 February } 2020 \\
\text { Available Online: } \\
\text { 10 March } 2020\end{array}$ \\
\hline
\end{tabular}

\section{A B S T R A C T}

Agriculture is the basis of rural economy and livelihood of developing nations where most of the farmers belong to small and marginal categories. Agriculture in developing nations had three contrasting divergence viz. Irrigated agriculture, Rainfed agriculture and Dryland agriculture, however, agriculture is considered as the best mean to reduce the rural poverty. According to Wikipedia, Poverty is not having enough material possessions or income for a person's needs. Poverty may include social, economic, and political elements. Sixty five per cent of the world's hungry live in only seven countries - India, China, Democratic Republic of Congo, Bangladesh, Indonesia, Pakistan and Ethiopia. Ever since the independence, India has witnessed poverty and increasing population as the core and harsh challenge to act on. So, Government's initial initiatives focussed on exploiting the potentials of agriculture to address the major and urgent need for food security that led to the introduction of Green Revolution during 1960s in the country. During this phase, the extension people acted as agents for technology transfer. As a result, India became selfsufficient in food grain reserves but still the condition of farmers were miserable. The following decades witnessed launch of several programmes for development with social justice for small and marginal farmers in particular and rural area in general, employment generations schemes for rural youth and women, etc. The extension system has played crucial role in agriculture and so is the extension professionals. They have assumed various roles from time to time and made a greater, efficient and valuable contribution in the changed scenario of demand driven to market driven agriculture. This paper briefs the changing role of pluralistic agriculture extension in agricultural growth and suggests the relevant policy implications.

\section{Introduction}

Agriculture is the basis of rural economy and livelihood of developing nations. In developing nations, most of the farmers are small and marginal categories/smallholder category. As per the World Bank report smallholder farmers are the future of world agriculture and they are shouldering and would continue to feed world population.

Developing nations' agriculture had three
contrasting divergence viz. Irrigated agriculture, Rainfed agriculture and Dryland agriculture, however, agriculture is considered as the best mean to reduce the rural poverty.

In most developing countries, agriculture and agriculture-related activities provide most of the employment in rural areas. The 
implication is that agricultural workers are poorly paid and most of the employees in the agricultural sector are unskilled. This also means "that increasing agricultural growth may have a large positive impact on poverty (Lopez, 2002). Hazell (1999) opined that with appropriate government policies and investments, institutional development and agricultural research, there is no reason why agricultural development cannot simultaneously contribute to growth, poverty alleviation, and environmental sustainability.

The significant progress in promoting economic growth, reducing poverty and enhancing food security cannot be achieved in most of these countries without developing more fully the potential human and productive capacity of the agricultural sector and enhancing its contribution to overall economic and social development. A strong and vibrant food and agricultural system thus forms a primary pillar in the strategy of overall economic growth and development(FAO,2002).

However, the paradoxes of developing nation's agricultural system are:

Farmers are conscious about their problems and in search of the solution. The research systems have solutions of farmers problems on farming

Farmers are residing in remote location and research station and experts are away or not always available to the farming community.

Public and private extension systems are there, however, only 20 per cent developed technologies reach to the farmers.

It is fact that there is a gap of technology diffusion by extension system and technology adoption by farmers.

Number of studies corroborated that increase income and technology adoption are positively and significantly correlated (Panda,2014), access to new agricultural technology affected the poor farmers directly, by raising the incomes of farm households(Diagne et. al., 2009).

In this liberalised economy, the group approach in extension, market led extension, public-private partnership and ICT in agricultural extension(Chandrashekara,2011) created huge opportunities to overcome farming problem and increase income of the farmers. World Bank, Asian Development Bank and International Fund for Agricultural Development and other international organisation and donor agencies(both national and international) had come up with the findings that without agricultural development inclusive growth is not possible.

The strengthening of agriculture can directly play a role in rural poverty alleviation and it also contributes indirectly to alleviate rural poverty by strengthening non-agricultural activities viz. fisheries, poultry, beekeeping, mushroom cultivation, goatary, piggery etc. Agriculture and allied sectors are sources of income for landless labourers. Indirectly growth in rural economy play catalytic role in industrial growth. However, there is a major change in agriculture from subsistence farming to market driven agriculture. Agriculture becomes the major income source for the smallholder farmers' food security, nutritional security, children's education, medical expenditure and so on. As the agriculture is prompted to market driven, so it becomes knowledge intensive. The knowledge intensive agriculture seeks timely information delivery. Twenty first century agriculture is facing this challenge of timely delivery of information to the farmers. It is the sending of right information, in the right mean to right farmers at the right time. Information and Communication 
Technology(ICT) becomes buzz words in agricultural extension in its different form viz. Agri-mobile Apps (Kisan Subidha, IFFCO Kisan, RLM Farmer, Pusa Krishi, Kheti Badi, Plantix, etc.), Social Media(youtube, whatsapp, facebook, twitter, etc.), video conferencing, mobile SMS, SD Card. In developing nations public extension system immensely contribute in technology transfer and it is mostly done by state department of agriculture, Krishi Vigyan Kendras (KVKs), Agricultural Universities. However, private extension delivery system viz. Multinational Companies (Seed, Fertilizer, Pesticide, etc.) also contribute in technology transfer.

Nonparametric productivity analyses performed to date show that most developing countries are experiencing relatively rapid technical regress in agriculture. The plausibility of these results and argue that they stem from the existence of biased technical change and the definition of technology used (Nin et al., 2003). Enhancing agricultural productivity in the developing world requires new approaches that provide incentives and funding mechanisms that promote the translation of new innovations in plant science into concrete benefits for poor farmers.

For a few crops with viable markets, such as maize and cotton, some of the traits developed by the private sector are already showing benefits for farmers of the developing world, but the public sector will need to develop new skills and overcome a number of hurdles to carry out similar efforts for other crops and traits useful to very poor farmers (Delmer, 2005).

\section{Different Extension Approaches}

Since the genesis of the extension, extension has gone through number of changes in approaches. The Food and Agricultural Organisation had categories the different extension approaches as shown below-

\begin{tabular}{|c|c|c|}
\hline $\begin{array}{c}\text { Extension } \\
\text { Approaches }\end{array}$ & Modus operandi & Remark \\
\hline $\begin{array}{c}\text { The general } \\
\text { extension } \\
\text { approach }\end{array}$ & $\begin{array}{c}\text { This approach assumes that technology } \\
\text { and knowledge that are appropriate for } \\
\text { local people exist but are not being used } \\
\text { by them. The approach is usually fairly } \\
\text { centralized and government-controlled. }\end{array}$ & $\begin{array}{c}\text { Success is measured in the adoption } \\
\text { rate of recommendations and } \\
\text { increases in national production. }\end{array}$ \\
$\begin{array}{c}\text { The } \\
\text { commodity } \\
\text { specialized } \\
\text { approach }\end{array}$ & $\begin{array}{c}\text { The key characteristic of this approach } \\
\text { groups all the functions for increased } \\
\text { production - extension, research, input } \\
\text { supply, marketing and prices - under one } \\
\text { administration. }\end{array}$ & $\begin{array}{c}\text { Extension is fairly centralized and is } \\
\text { oriented towards one commodity or } \\
\text { crop and the agent has many } \\
\text { functions }\end{array}$ \\
$\begin{array}{c}\text { The training } \\
\text { and visit } \\
\text { approach }\end{array}$ & $\begin{array}{c}\text { This fairly centralized approach is based } \\
\text { on a rigorously planned schedule of } \\
\text { visits to farmers and training of agents } \\
\text { and subject matter specialists. Close } \\
\text { links are maintained between research } \\
\text { and extension. Agents are only involved } \\
\text { in technology transfer. }\end{array}$ & $\begin{array}{c}\text { Success is related to increases in the } \\
\text { production of particular crops or } \\
\text { commodities. }\end{array}$ \\
\hline $\begin{array}{c}\text { The } \\
\text { agricultural }\end{array}$ & $\begin{array}{c}\text { This approach often focuses on the } \\
\text { expressed needs of farmers' groups and }\end{array}$ & $\begin{array}{c}\text { Success is measured by the numbers } \\
\text { of farmers actively participating and }\end{array}$ \\
\hline & & \\
\hline
\end{tabular}




\begin{tabular}{|c|c|c|}
\hline $\begin{array}{c}\text { extension } \\
\text { participatory } \\
\text { approach }\end{array}$ & $\begin{array}{l}\text { its goal is increased production and an } \\
\text { improved quality of rural life. }\end{array}$ & $\begin{array}{c}\text { the sustainability of local extension } \\
\text { organizations. }\end{array}$ \\
\hline $\begin{array}{l}\text { The project } \\
\text { approach }\end{array}$ & $\begin{array}{l}\text { This approach concentrates efforts on a } \\
\text { particular location, for a specific time } \\
\text { period, often with outside resources. } \\
\text { Part of its purpose is often to } \\
\text { demonstrate techniques and methods } \\
\text { that could be extended and sustained } \\
\text { after the project period. }\end{array}$ & $\begin{array}{l}\text { Change in the short term is often a } \\
\text { measure of success. }\end{array}$ \\
\hline $\begin{array}{l}\text { The farming } \\
\text { systems } \\
\text { development } \\
\text { approach }\end{array}$ & $\begin{array}{l}\text { A key characteristic of this type of } \\
\text { extension is its systems or holistic } \\
\text { approach at the local level. Close ties } \\
\text { with research are required and } \\
\text { technology for local needs is developed } \\
\text { locally through an interactive process } \\
\text { involving local people. }\end{array}$ & $\begin{array}{l}\text { Success is measured by the extent to } \\
\text { which local people adopt and } \\
\text { continue to use technologies } \\
\text { developed by the programme. }\end{array}$ \\
\hline $\begin{array}{l}\text { The cost- } \\
\text { sharing } \\
\text { approach }\end{array}$ & $\begin{array}{l}\text { This approach assumes that cost-sharing } \\
\text { with local people (who do not have the } \\
\text { means to pay the full cost) will promote } \\
\text { a programme that is more likely to meet } \\
\text { local situations and where extension } \\
\text { agents are more accountable to local } \\
\text { interests. Its purpose is to provide } \\
\text { advice and information to facilitate } \\
\text { farmers' self-improvement. }\end{array}$ & $\begin{array}{l}\text { Success is often measured by the } \\
\text { willingness to pay. }\end{array}$ \\
\hline $\begin{array}{c}\text { The } \\
\text { educational } \\
\text { institution } \\
\text { approach }\end{array}$ & $\begin{array}{l}\text { This approach uses educational } \\
\text { institutions which have technical } \\
\text { knowledge and some research ability to } \\
\text { provide extension services for rural } \\
\text { people. Implementation and planning } \\
\text { are often controlled by those who } \\
\text { determine school curricula. }\end{array}$ & $\begin{array}{l}\text { The emphasis is often on the transfer } \\
\text { of technical knowledge. }\end{array}$ \\
\hline
\end{tabular}

Ballantyne and Bokre, (2003) had concluded that extension as aiming to:

Improve the wellbeing of individuals and communities

Change production systems so that they improve rural livelihoods and sustain the resources - Improve agriculture and the social, economic and political status of rural communities

Improve the wellbeing of farm families

Improve productivity and livelihoods for farmers

Increase and improve farmers' income and productivity on a sustainable basis

Enhance farmers' production

Attain higher levels of efficiency in the farm enterprise

Attain food security and improve rural livelihoods.

\section{Poverty and related statistics}

According to Wikipedia, Poverty is not 
having enough material possessions or income for a person's needs. Poverty may include social, economic, and political elements. Absolute poverty is the complete lack of the means necessary to meet basic personal needs, such as food, clothing and shelter. The threshold at which absolute poverty is defined is always about the same, independent of the person's permanent location or era.

Ever since the independence, India has witnessed poverty and increasing population as the core and harsh challenge to act on. While the resources grow arithmetically, population grows geometrically. Of all the basic human needs, need for food is the prime requirement and the poverty is often revealed through hunger estimates. According to Food and Agriculture Organization (FAO) of the United Nations (2011), hunger is the consumption of less than 1800 calories per day.

According to World Food Programme, 98 per cent of the world's hungry live in the developing countries. Asia-Pacific Region is inhabited by around half of the world's population and two-third of the world's hungry people.

Sixty five per cent of the world's hungry live in only seven countries - India, China, Democratic Republic of Congo, Bangladesh, Indonesia, Pakistan and Ethiopia (http://www.cocoponics.co). India is the home of $17.31 \%$ (1.21billion; March 2011) of the world's population but ranks the third poorest. Global Hunger Index ranks India 67th out of the 122 developing countries. The India Chronic Poverty Report observes that about $65 \%$ of the poor in India live in eight (out of twentyeight) States: Uttar Pradesh, Bihar, Maharashtra Madhya Pradesh, Orissa, Jharkhand, Chhattisgarh and Uttarakhand. These poorest States also have to contend with the largest and fastest growing populations (One World Guides-India Briefings, 2011).

The 1979 Planning Commission task force on poverty estimation reported 2400 calories requirement at minimum consumption expenditure of Rs. 49.1 (Rs per capita per month) for a person in rural area and 2100 calories costing at Rs. 56.7 in urban areas. Official statistics show that poverty measured in terms of headcount ratio (HCR) declined from $54.9 \%$ in $1973-74$ to $27.5 \%$ in $2004-05$, but the pace of poverty reduction over the past decade has been slow.Poverty declined by 12.4 percentage points over the decade from $1977-78$ to $1987-88$, but by only 8.5 percentage points between 1993-94 and 200405 .

\section{Agriculture as potential transformer from food deficit to food surplus}

At the time of independence of India, agriculture was the main occupation of its people and the economy rested on it. So, Government's initial initiatives focussed on exploiting the potentials of agriculture to address the major and urgent need for food security. This led to the Green Revolution during 1960s in India. It introduced improved varieties that yielded much higher than the existing cultivars cultivated by the farmers.

These varieties were input intensive and required technical know how about the package of practices. Though the Green Revolution made India self-sufficient in food grain reserves still the condition of farmers were miserable. This inclined the focus of the Government towards their condition and hence, the decade of 1970 s to mid1980s witnessed launch of several programmes for development with social justice for small and marginal farmers in particular and rural area in general. Further the target group expanded from mere farmers to agricultural labourers, 
rural youth and women with the introduction of TRYSEM (Training of Rural Youth for Self-Employment) and DWCRA (Development of Women \& Children in Rural Areas). Also the establishment of Krishi Vigyan Kendras (KVKs) was done to strengthen institutional operation and World Bank funded Training \& Visit (T\&V) programme was launched to make the contemporary programmes more efficient and effective.

Several employment generation schemes such as Jawahar Rozgar Yogana (JRY), Employment Assurance Scheme (EAS), Swarna Jayanti Gram Swarozgar Yojana (SGSY), etc.were launched at the end of $20^{\text {th }}$ century. These schemes were launched because most farmers belonged to small or marginal category who do not have sufficient income to afford advanced agricultural technological packages and meet the personal and social obligations such as good education, access to medical facilities, children marriage, etc.

During the era of globalisation and liberalisation at the end of the $20^{\text {th }}$ century resulted in the opening of the global market. It evolved the need for competence of Indian market with the world standards which in turn called for an overhauling in the Indian agricultural endeavour.

Thus, the programmes like National Agricultural Technology Project (NATP), National Agricultural Innovation Project (NAIP), etc. came into the picture. The overall objective of which is to facilitate accelerated and sustainable transformation of Indian agriculture for rural poverty alleviation and income generation by the application of agricultural innovations through collaboration among public research organizations, farmers' groups, NGOs, the private sector and the civil societies and other stakeholders. By the time of beginning of $21^{\text {st }}$ century, India had developed export potential and made buffer stock of food grains to meet dual global challenges of hunger and poverty which is reflected from the launch of the National Horticulture Mission (NHM) and National Food Security Mission (NFSM).

As per the land use statistics 2014-15, total geographical area of the country is 328.7 million hectares, of which reported net sown area is 140.1 million hectares and the gross cropped area is 198.4 million hectares with a cropping intensity of 142 percent. Agriculture plays a vital role in India's economy. 54.6\% of the population is engaged in agriculture and allied activities (census 2011) and it contributes $17.4 \%$ to the country's Gross Value Added for the year 2016-17 (at current prices).

Given the importance of agriculture sector, Government of India took several steps for its sustainable development. Steps have been taken to improve soil fertility on a sustainable basis through the soil health card scheme, to provide improved access to irrigation and enhanced water efficiency through Pradhan Mantri Krishi Sinchai Yojana (PMKSY), to support organic farming through Paramparagat Krishi Vikas Yojana (PKVY) and to support for creation of a unified national agriculture market to boost the income of farmers. Further, to mitigate risk in agriculture sector a new scheme, Pradhan Mantri FasalBima Yojana (PMFBY) has been launched forimplementation from Kharif 2016.

\section{Role dynamics of agricultural extension in agricultural development}

The origin of agricultural extension services is dated back to the period of Irish famine when it was need to disseminate agricultural information to people for alternatives to 
potato and developed agricultural technologies. The efforts were later systematised and gave birth to University extension in the United Kingdoms. This gave rise to the two dimension of extension. One being the extension education and other being the extension services, both of which operates in a non-formal mode.

The earliest extension efforts in India till its independence were made individuals, mostly single handily. With the establishment of Indian Council of Agricultural Research (ICAR) in 1929, a more formalised and institutional system was generated that added research as another dimension. ICAR is the apex institution that has a network of research institutes, KVKs, research stations, agricultural and allied universities that make it the worlds'largest agricultural system. The scientists of agricultural universities, KVKs and the staffs of State Department of Agriculture are the core extension professionals catering the needs of the farmers. Agriculture is the predominant scenario in the rural India, hence, they are served by the Ministry of Agriculture \& Farmers' Welfare and the Ministry of Rural Development.

Just after independence, the major challenge of poverty was considered to be addressed by securing food surplus with the introduction of the Green Revolution in agriculture. During this phase, extension workers assumed the role of transfer of technology (ToT) agents who not only demonstrated the package of practices on improved and high yielding varieties but also acted as supply agents to deliver the inputs to the farmers. They were the two way linkage between research institutions and the farmers who take the improved agricultural technologies to the clients and make them feasible for their adoption in farmers' field conditions. At the same time, identified needs and problems of the clients and brought it back to the research institutions. In the decade of 1970s, they acted as key communicators and facilitators to advance benefits of the development with social justice programmes of the government to the target groups.

They played the role of management personnel and trainers during 1980s to develop capacity of clienteles including rural youth and women for employment generation. They expanded the scope beyond agriculture introducing practices like beekeeping, mushroom cultivation, sericulture, etc.In the era of globalisation and liberalisation, the extension professionals transformed themselves to the role of motivators and promoters to enhance competitiveness of Indian farmers in the global scenario by linking them directly with the markets.

The government has established institutions like Extension Education Institutes (EEIs), MANAGE, etc. and several programmes to cater to the needs of extension workers and develop their capabilities. For performing all these varied roles, they adopted various tools, techniques and methods appropriate from time to time that increased their effectiveness and usefulness in the pluralistic extension system of India.

The use of Information and Communication Technologies (ICTs) has proved most useful for them especially in the changed scenario of demand driven approach to market driven approach. Though known by various names, the agricultural extension workers have always been identified as change agents. 
Table.1 Poverty trends, $1973-74$ to $2004-05$

\begin{tabular}{|c|c|c|}
\hline Years & $\begin{array}{c}\text { \% of Population below } \\
\text { poverty line }\end{array}$ & $\begin{array}{c}\text { Total population in } \\
\text { poverty(millions) }\end{array}$ \\
\hline $\mathbf{1 9 7 3 - 7 4}$ & 54.9 & 321.3 \\
\hline $\mathbf{1 9 7 7 - 7 8}$ & 51.3 & 328.9 \\
\hline $\mathbf{1 9 8 3}$ & 44.5 & 322.9 \\
\hline $\mathbf{1 9 8 7 - 8 8}$ & 38.9 & 307.1 \\
\hline $\mathbf{1 9 9 3 - 9 4}$ & 36 & 320.3 \\
\hline $\mathbf{1 9 9 9 - 0 0}$ & 26.1 & 260.2 \\
\hline $\mathbf{2 0 0 4} \mathbf{- 0 5}$ & 27.5 & 301.70 \\
\hline
\end{tabular}

Source - Planning Commission (1997); Press Information Bureau $(2001,2007)$

Poverty is global challenge and a major issue in developing nations. Agriculture being the backbone of developing nation's economy has potential to address this challenge. Since independence, India has witnessed decadal changes in agricultural development programmes that have transited through food production, employment generation to income generation approaches for alleviating poverty.

The extension system has played crucial role in agriculture and so are the extension professionals. They have assumed various roles from time to time and made a greater, efficient and valuable contribution in the changed scenario of demand driven to market driven agriculture. The uses of ICTs have proved very useful for extension in recent era in making farmers to meet global competition. So, under this backdrop there is a need to relook the changing role of agriculture extension to contribute in agricultural growth and following policy implication is suggested:

Pluralistic and participatory extension delivery system.

Mainstreaming farm women in agriculture.

Dissemination of climate resilient technology. Use of Artificial Intelligence in Precision Farming and allied sectors.

Promote the development of appropriate community-based ICT endeavours for sharing climate change information and technology options.

Strengthening market lead extension.

Change the institutional role for more involvement of farm women in agriculture.

Promoting small agri-implements technology among smallholder farmers.

Proper utilization of small operational holdings of smallholder farmers.

Formation of Farmers Producer Organization and other group approaches for getting better market price.

Inclusion of poultry, goatary, beekeeping, mushroom cultivation, vegetable crops and other cash crops and remunerative enterprises.

Promoting Resource Conservation Technology(RCT) among smallholder farmers.

Convergence of different stakeholders in policy decision in agricultural extension.

Promoting Agri-enterprises through rural youth.

\section{References}

Ballantyne, P. and Bokre, D. (2003) Report from the 'PrepCom' (for CTA's Sixth Consultative Expert Meeting of its 
Observatory on ICTs). Wageningen, the Netherlands: CTA.

Bhattacharjee, S and Saravanan, R., (2012). Poverty in Natural Prosperity: Can Agriculture Bring the Renaissance in NorthEast India?. In: Kashyap, Shivendra Kumar,Pathak, Awadhesh and Papnai Gaurav (Eds). Saving Humanity- Swami VivekanandaPerspective. Published by Vivekanand Swadhyay Mandal, G.B. Pant University of Agriculture and Technology, Pantnagar, Uttarakhand. Pp261-275.

Chandrashekara, P. (2011). Facilitating PublicPrivate-Partnership. In K.D. Kolkata, A.K. Mehta, A.K. Singh, L.Singh \& P. Adiguru (Eds.), Future Agriculture Extension (pp.7477). New Delhi: Westville Publishing House.

Cocoponics (2011). How can you fight hunger with hydroponics. Published on 31st March, 2011. http://www.cocoponics.co (Accessed on 1st November, 2011).

Delmer, D. P. (2005). Agriculture in the developing world: connecting innovations in plant research to downstream applications. Proceedings of the National Academy of Sciences, 102(44), 1573915746.

Diagne, A., Adekambi, S.A., Simtowe, F.P., \& Biaou, G. (2009). The Impact of Agricultural Technology Adoption on Poverty: The Case of Nerica Rice Varieties in Benin. The 27th Conference of the International Association of Agricultural Economists. August 16-22, 2009. Beijing, China.

FAO. (2011) The State of Food Insecurity in the World 2011. Food and Agriculture Organization of the United Nations, Rome. 2011. http://www.fao.org/catalog/intere.
Hazell, P. B. (1999). Agricultural growth, poverty alleviation, and environmental sustainability: Having it all (No. 59). International Food Policy Research Institute (IFPRI).

Lopez, R (2002). Agricultural Growth and Poverty Reduction. Socio-economic Analysis and Policy Implications of the Roles of Agriculture in Developing Countries. Roles of Agriculture Project, Food and Agriculture Organization, Rome, Italy.

Nin, A., Arndt, C., \& Preckel, P. V. (2003). Is agricultural productivity in developing countries really shrinking? New evidence using a modified nonparametric approach. Journal of Development Economics, 71(2), 395-415.

One World Guides (2011). Briefings on poverty, food security and energy in India in the context of climate change, produced by OneWorld Guides. 4th October, 2011. http://www.oneworldgroup.org (Accessed on 9th November, 2011).

Panda, C.K. (2014). Socio-Economical Factors and Their Interrelationship for Farm Technology Adoption: The Case of Selected Villages of Mohanpur R.D. Block, West Tripura. In National Seminar on "Economic Development-Contemporary Issues". Organised by Department of Economic with Rural Development, Vidyasagar University, Midnapore, West Bengal.

Press Information Bureau (2001) 'Poverty Estimates for 1999-2000.' Press Release, February. New Delhi: Press Information Bureau

Press Information Bureau (2007) 'Poverty Estimates for 2004-2005.' Press Release, March. Press Release, February. New Delhi: Press Information Bureau.

\section{How to cite this article:}

Chandan Kumar Panda, Aditya Karn and Ravindra Kumar Sohane. 2020. Agriculture for Poverty Alleviation: The Changing Role of Agricultural Extension in Developing Nations. Int.J.Curr.Microbiol.App.Sci. 9(02): 452-500. doi: https://doi.org/10.20546/ijcmas.2020.902.057 